\title{
Desertification and a shift of forest species in the West African Sahel
}

\author{
Patrick Gonzalez* \\ Earth Resources Observation Systems Data Center, US Geological Survey, Washington, DC 20523-4600, USA
}

\begin{abstract}
Original field data show that forest species richness and tree density in the West African Sahel declined in the last half of the 20th century. Average forest species richness of areas of $4 \mathrm{~km}^{2}$ in Northwest Senegal fell from $64 \pm 2$ species ca 1945 to $43 \pm 2$ species in 1993, a decrease significant at $p<0.001$. Densities of trees of height $\geq 3 \mathrm{~m}$ declined from $10 \pm 0.3$ trees ha $^{-1}$ in 1954 to $7.8 \pm 0.3$ trees $\mathrm{ha}^{-1}$ in 1989 , also significant at $\mathrm{p}<0.001$. Standing wood biomass fell $2.1 \mathrm{t} \mathrm{ha}^{-1}$ in the period 1956-1993, releasing $\mathrm{CO}_{2}$ at a rate of $60 \mathrm{kgC}$ person ${ }^{-1} \mathrm{yr}^{-1}$. These changes have shifted vegetation zones toward areas of higher rainfall at an average rate of 500 to $600 \mathrm{~m} \mathrm{yr}^{-1}$. Arid Sahel species have expanded in the north, tracking a concomitant retraction of mesic Sudan and Guinean species to the south. Multivariate analyses identify latitude and longitude, proxies for rainfall and temperature, as the most significant factors explaining tree and shrub distribution. The changes also decreased human carrying capacity to below actual population densities. The rural population of 45 people $\mathrm{km}^{-2}$ exceeded the 1993 carrying capacity, for firewood from shrubs, of 13 people $\mathrm{km}^{-2}$ (range 1 to 21 people $\mathrm{km}^{-2}$ ). As an adaptation strategy, ecological and socioeconomic factors favor the natural regeneration of local species over the massive plantation of exotic species. Natural regeneration is a traditional practice in which farmers select small field trees that they wish to raise to maturity, protect them, and prune them to promote rapid growth of the apical meristem. The results of this research provide evidence for desertification in the West African Sahel. These documented impacts of desertification foreshadow possible future effects of climate change.
\end{abstract}

KEY WORDS: Desertification · Forest biodiversity $\cdot$ Land cover change $\cdot$ Natural regeneration of forest species · Senegal · Vegetation zone shift · West African Sahel

Resale or republication not permitted without written consent of the publisher

\section{INTRODUCTION}

Environmental change and evolving patterns of human activity have produced a precarious situation in the West African Sahel. Today, a growing population can provide for its subsistence needs only with difficulty on a land whose productivity has degraded markedly since the mid-20th century (UNDP 1997 , UNEP 1997). Formerly productive land has declined through the process of desertification, defined by the United Nations Convention to Combat Desertification

*E-mail: pgonzalez@usgs.gov
(UNCCD) as 'land degradation in arid, semi-arid, and dry sub-humid areas resulting from various factors, including climatic variations and human activities' (UNCCD 1994). Desertification in West Africa culminated in the Sahel drought of 1968-1973, a tragedy that witnessed famine and the death of up to a quarter of a million people (CDC 1973, UNCOD 1977).

Feedbacks between land degradation and precipitation link desertification and climate change. Desertification aggravates climate change through the release of $\mathrm{CO}_{2}$ from cleared and dead vegetation and through the reduction of the carbon sequestration potential of desertified land. Conversely, climate change exacerbates desertification through the alteration of spatial 


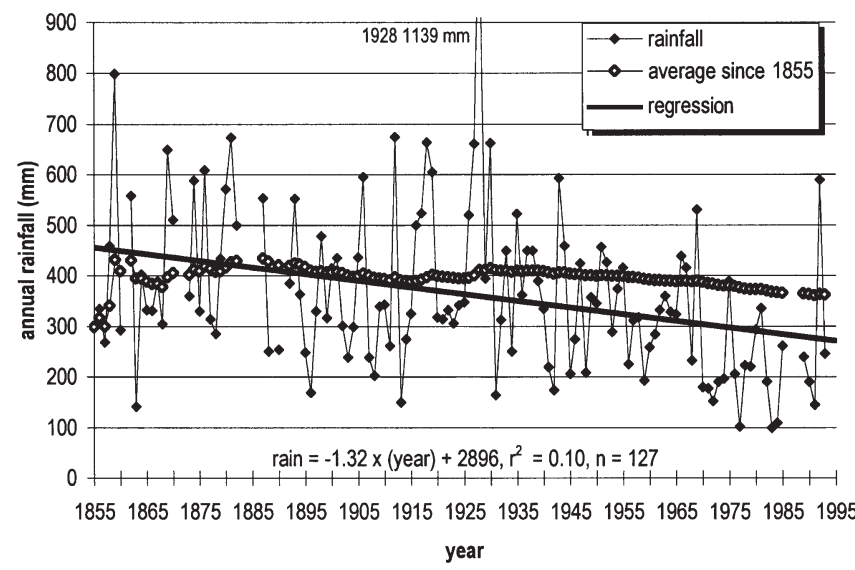

Fig. 1. Annual rainfall (mm) at St. Louis (Ndar), Senegal, 1855-1993. Data from Aubréville (1938) and from the Direction de la Méteorologie Nationale, Dakar, Senegal

and temporal patterns of temperature, precipitation, solar insolation, and winds.

Forest species guard against desertification and climate change through the provision of multiple ecosystem services, including soil erosion control, storage and transpiration of the water required for precipitation, carbon sequestration, and the formation of habitats for a diverse array of plant and animal species. Not only do trees and shrubs provide these ecosystem services, but they also provide firewood, structural timber, traditional medicines, staple foods, and drought emergency foods.

This report presents the results of ecological and socioeconomic field research (Gonzalez 1997) that documents a large-scale decline in forest species richness and tree densities in the Sahel. These results provide evidence for desertification in the West African Sahel. The research also analyzed human carrying capacity, the number of people that an ecosystem can support indefinitely under specified social circumstances (Gonzalez 1997). Finally, the research examined the natural regeneration of local species as the possible key to sustainable natural resource management.

The research addresses a lack of field documentation of the changes in forest biodiversity, tree density, and human carrying capacity in the Sahel. Limited studies (Shantz \& Turner 1958, Poupon 1980, Olsson 1984, Lericollais 1988, Frankenberg \& Anhuf 1989) have issued only anecdotal reports on changes in forest biodiversity and tree densities. Past estimates of carrying capacity (Gorse 1985, Kessler 1994) lacked field data. Finally, the examination of the practice of natural regeneration seeks to address the neglect of this practice, due, in part, to donor emphasis on the plantation of exotic species (World Bank 1988, FAO 1999).

\section{RESEARCH AREA AND METHODS}

The research area covers the $7600 \mathrm{~km}^{2}$ of land between $15^{\circ} 00^{\prime}$ and $16^{\circ} 01^{\prime} \mathrm{N}$ and between $16^{\circ} 00^{\prime}$ and $16^{\circ} 42^{\prime} \mathrm{W}$ in the Republic of Senegal on the west coast of Africa. In 1988, it was home to 485000 people living at an average density of 45 people $\mathrm{km}^{-2}$ in rural areas and 64 people $\mathrm{km}^{-2}$ overall (République du Sénégal 1988). The Wolof ethnic group constitutes the majority, with $84 \%$ of the population (Gonzalez 1997). Threequarters of the population engage in rain-fed agriculture on three-quarters of the land, with the remaining space left to semi-nomadic pastoralism (Gonzalez 1997).

Fixed sand dunes oriented NNE-SSW dominate the area, with the most pronounced dunes of up to $10 \mathrm{~m}$ height reaching across its north-central portion. Elsewhere, lesser dunes grade down to level plains. Entisols with sand fractions $>0.85$ cover almost all of the area (Maignien 1965, Zanté 1984, Stancioff et al. 1986).

Aridity marks the area's climate. At St. Louis (Ndar) $\left(16^{\circ} 3^{\prime} \mathrm{N}, 16^{\circ} 27^{\prime} \mathrm{W}\right)$, the 1855-1993 mean rainfall was $360 \pm 160 \mathrm{~mm} \mathrm{yr}^{-1}$ (Aubréville 1938; data from the Direction de la Méteorologie Nationale, Dakar, Sénégal) (Fig. 1). At Louga $\left(15^{\circ} 37^{\prime} \mathrm{N}, 1^{\circ} 14^{\prime} \mathrm{W}\right)$, the 1919-1993 mean precipitation was $400 \pm 160 \mathrm{~mm} \mathrm{yr}^{-1}$ (République Française 1925; data from the Direction de la Méteorologie Nationale, Dakar, Senegal). Le Houérou (1989) estimated a Penman potential evapo-

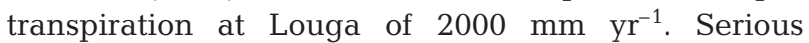
droughts have hit the area in the periods 1910-1914, 1942-1949, and 1968-1973.

A north-south latitudinal gradient of increasing rainfall derives from distance to the Equator; an east-west maritime gradient of decreasing temperature derives from distance to the Atlantic Ocean. Starting in the research area and extending across West Africa, the increasing rainfall and decreasing evapotranspiration toward the Equator differentiate vegetation into 3 latitudinal bands of increasingly mesic species: the vegetation zones of the Sahel, the Sudan, and Guinea (Aubrevillé 1950, White 1983).

Thorny tree species with small, deciduous, sclerophyllous, and bi-pinnately compound leaves characterize the Sahel. Trees occur singly and widely spaced, with small groves occurring in some cemeteries and interdunal valleys. In the Sudan, trees collect in small groves and form dense thickets in low-lying seasonal ponds and fossil valleys. Trees form an open layer 8 to $20 \mathrm{~m}$ in height. Most Sudanian tree species possess pinnately compound leaves with leaflets larger than Sahelian species and produce dense, slightly sweet fruits. In the Guinean zone, mesic species form a closed-canopy, broad-leaved evergreen forest. High 
precipitation and insolation bestow Guinean vegetation with an energy surplus that many forest species allocate to the production of dense timber or succulent fruit.

A decline in rainfall and an increase in human population have occurred at the same time throughout this century. Linear regression of the 1919-1993 Louga rainfall data yields a negative slope $\left(\mathrm{r}^{2}=0.10, \mathrm{p}<\right.$ 0.001), while the population of Senegal doubled in the period 1945-1988, growing at a rate of $0.025 \mathrm{yr}^{-1}$ (République Française 1950, République du Sénégal 1992). The trends in both rainfall and population remain consistent with trends across the Sahel (Hulme 1992, UN 1999, Nicholson 2000).

I defined a grid of squares $7.5 \mathrm{~km} \times 7.5 \mathrm{~km}$ that divides the research area into 135 cells. From August 1993 to June 1994, I hiked $1900 \mathrm{~km}$ and spent a day and night in each of 135 villages to conduct forest inventories and semistructured interviews. The research followed the principles of Participatory Rural Appraisal (Carruthers \& Chambers 1981, Chambers et al. 1989).

At the geographic center of each cell, I took an inventory of all trees and shrubs in a 1 ha quadrat. Centric systematic area sampling such as this produces a random sample (Milne 1959). Maps at 1:50 000 scale (République du Sénégal 1991) and 1989 aerial photos at 1:60000 scale (described later in this section) permitted establishment of the geographic center of each cell. I counted every tree and shrub in each quadrat and measured, for all trees of height $\geq 40 \mathrm{~cm}$, height $(h)$, diameter at $h=40 \mathrm{~cm}$, and, for trees of $h \geq 1.3 \mathrm{~m}$, diameter at $h=1.3 \mathrm{~m}$. For Acacia raddiana of $h \geq 40 \mathrm{~cm}$, I also measured the diameter at the ground (Coughenour et al. 1990). From trees of $h \geq 3 \mathrm{~m}$ near the quadrat centers, I extracted 137 wood cores using a $4.3 \mathrm{~mm}$ diameter 2-thread increment borer, measured heights and diameters, and photographed each tree.

The height and diameter measurements and wood cores permitted quantification of standing wood biomass and wood growth, using allometric equations (Poupon 1980, Coughenour et al. 1990) and growth rates (Catinot 1967, Giffard 1967, Cazet 1989, CTFT 1989) for West African species. Normalized difference vegetation index (NDVI) (Tucker 1979) data for the research area at $1.1 \mathrm{~km}$ resolution (CSE 1993), integrated over calendar year 1993 and correlated to biomass measurements across Senegal by the Centre de Suivi Écologique, permitted quantification of green biomass, the other component of total standing biomass. To calculate wood biomass of Boscia senegalensis, Combretum glutinosum, and Guiera senegalensis, the 3 shrubs that local people coppice for firewood, I measured branch volumes on 2 uncut 1 ha quadrats in the 'Arrondissement de Sakal' near the center of the research area and measured densities from wood samples gathered in the same area.

At the village on whose land the 1 ha quadrat lay or at the village closest to the quadrat, I spoke with 2 elders, 1 man and 1 woman, concerning their perceptions of environmental change. Each village chose the 2 elders to speak according to 3 criteria determined by the author: age $\sim 65 \mathrm{yr}$ in order to check the ranges of species at the time of the 1940s drought, knowledge of local flora, and continuous residence in the village. Semistructured interviews centered on a set of 10 precisely worded questions, although flexible discussions ranged over many topics. The first question consisted of a systematic check of the presence or absence of the 126 tree and shrub species in the research area (Table 1) ca 1945 and in 1993. To fix the time period of the historic species ranges, I specified that I was asking about the time period of the 1942-1949 drought. Therefore, the results on historic species ranges apply to a time around 1945.

Recollections of the historical presence or absence of species served as a proxy for non-existent data on historical distributions. Although recollections are inexact, the research required only 1 point of binary information: presence $=1$, absence $=0$. Restricting species richness data to this 1 point avoided the errors that more extensive questions would have introduced. In order to quantify the error of recollection of the male elders, the author recorded corrections made to ca 1945 recollections by male peers in group discussions or in individual conversations separate from the semistructured interviews, corrections to ca 1945 and 1993 data made by female elders, and corrections made from my observations of 1993 species distributions. Corrections to data from male elders amounted to only $1 \%$ of 34020 data points.

The conviction with which most elders identified the presence or absence of species and the cogent manner in which they discussed the local flora demonstrated their thorough knowledge of natural history. Indeed, elders often identified the exact location of the last individual of a species that had disappeared from village lands. Countless times, farmers sat down in their compounds and provided running narrations of the layout of their fields, complete with the locations of individual trees. Vansina (1961) has examined African oral traditions and validated their general historical accuracy.

Examination of 137 aerial photos taken by the Institut Géographique National (IGN) of France and 83 aerial photos taken by the Japanese International Cooperation Agency (JICA) permitted quantification of total tree densities. IGN photographed the research area in February 1954 during Missions AOF 083 ND-28-XX and AOF 087 NE-28-II. IGN photos at 1:52500 scale 
Table 1. Flora of northwest Senegal (Gonzalez 1997). Vegetation zone affiliations for 106 species from Aubréville (1950) and Trochain (1940). Affiliations of other species are based on climate requirements and botanical characteristics. For the Wolof names, [text] indicates alternative names, (text) indicates the reason for an alternative name. $\mathrm{S}=$ southern part of the research area

\begin{tabular}{|c|c|c|c|c|}
\hline Species & Wolof name & Botanist & Family & $\begin{array}{l}\text { Vegetation } \\
\text { zone }\end{array}$ \\
\hline Acacia albida & Kàdd & Del. & Mimosaceae & Sudan \\
\hline Acacia ataxacantha & Déd & DC. & Mimosaceae & Sudan \\
\hline Acacia macrostachya & Sam, Cam (South) & Reichenb. ex Benth. & Mimosaceae & Sudan \\
\hline Acacia nilotica adansonii & Neb Neb & (Guill. et Perrott.) O. Ktze. & Mimosaceae & Sahel \\
\hline Acacia nilotica tomentosa & Gonake & (Benth.) A.F. Hill. & Mimosaceae & Sahel \\
\hline Acacia raddiana & Séng & Savi & Mimosaceae & Sahel \\
\hline Acacia senegal & Verek & (L.) Willd. & Mimosaceae & Sahel \\
\hline Acacia seyal & Fonax (green), Surur (red) & Del. & Mimosaceae & Sahel \\
\hline Acacia sieberiana & Sandandur & DC. & Mimosaceae & Guinea \\
\hline Achras sapota & Sàppóoti & $\mathrm{L}$. & Sapotaceae & Guinea \\
\hline Adansonia digitata & Guy & L. & Bombacaceae & Sudan \\
\hline Adenium obesium & Liisugaar & (Forsk.) Roem. et Schult. & Apocynaceae & Sudan \\
\hline Afrægle paniculata & Kunsay, Ngunsay & (Schum.) Engl. & Rutaceae & Guinea \\
\hline Afrormosia laxiflora & Kulukulu & Harms. & Fabaceae & Guinea \\
\hline Agave sisalana & Yoos, Bissaw (South) & $\mathrm{L}$. & Agavaceae & Sudan \\
\hline Anacardium occidentale & Darkase & L. & Anacardiaceae & Sudan \\
\hline Annona glauca & Dugor Yunoori & Thonn. & Annonaceae & Guinea \\
\hline Annona senegalensis & Dugor Mer & Pers. & Annonaceae & Guinea \\
\hline Anogeissus leiocarpus & Ngejan, Gejj (South) & (DC.) Guill. et Perrott. & Combretaceae & Guinea \\
\hline Aphania senegalensis & Xewar & Radlk. & Sapindaceae & Guinea \\
\hline Avicennia africana & Sanaar & P. Beauv. & Avicenniaceae & Guinea \\
\hline Balanites ægyptiaca & Sump & (L.) Del. & Balanitaceae & Sahel \\
\hline Bauhinia rufescens & Rand & Lam. & Caesalpiniaceae & Sudan \\
\hline Bombax costatum & Garabu Lawbe, Dundul, Guy Jeeri & Pellegr. et Vuillet & Bombacaceae & Guinea \\
\hline Borassus æthiopium & Ron, Xadin (small) & Mart. & Palmae & Sudan \\
\hline Boscia angustifolia & Nus & A. Rich. & Capparidaceae & Sahel \\
\hline Boscia senegalensis & Njandam & (Pers.) Lam. ex Poir. & Capparidaceae & Sahel \\
\hline Cadaba farinosa & Ndeybarga, Ndeymarga (S) & Forsk. & Capparidaceae & Sahel \\
\hline Calotropis procera & Paftan, Faftan (South) & (Ait.) Ait. F. & Asclepiadaceae & Sahel \\
\hline Capparis tomentosa & Xareñ & Lam. & Capparidaceae & Sudan \\
\hline Cassia occidentalis & Bànta[e(S)]mare, Mbànta[e(S)] & L. & Caesalpiniaceae & Sudan \\
\hline Cassia sieberiana & Senjeñ & DC. & Caesalpiniaceae & Guinea \\
\hline Ceiba pentandra & Béntéñe & (L.) Gaertn. & Bombacaceae & Guinea \\
\hline Celtis integrifolia & Mbul & Lam. & Ulmaceae & Guinea \\
\hline Chrysobalanus orbicularis & [Wo]rajj & Schum. et Thonn. & Rosaceae & Guinea \\
\hline Cocculus pendulus & Sangool & (Forsk.) Diels & Menispermaceae & Sahel \\
\hline Cocos nucifera & Koko & L. & Palmae & Guinea \\
\hline Combretum aculeatum & Sawet & Vent. & Combretaceae & Sahel \\
\hline Combretum glutinosum & Rat, Rat bu Goor (resprout) & Perrott. ex DC. & Combretaceae & Sudan \\
\hline Combretum micranthum & Sexaw & G. Don & Combretaceae & Sudan \\
\hline Combretum nigricans & Taap & Lepr. ex Guill. et Perrott. & Combretaceae & Guinea \\
\hline Commiphora africana & Ngutoot & (A. Rich.) Engl. & Burseraceae & Sahel \\
\hline Cordia senegalensis & Bee Gile & Juss. & Cordiaceae & Guinea \\
\hline Cordyla pinnata & Dimb, Dimbu & (Lepr. ex A. Rich.) Milne-Redh. & Caesalpiniaceae & Guinea \\
\hline Crateva adansonii & Xoril, Xoritt (South) & DC. & Capparidaceae & Guinea \\
\hline Dalbergia melanoxylon & Jalamban & Guill. et Perrott. & Fabaceae & Sudan \\
\hline Detarium microcarpum & Dànq & Guill. et Perrott. & Caesalpiniaceae & Guinea \\
\hline Detarium senegalensis & Ditax & Gmel. & Caesalpiniaceae & Guinea \\
\hline Dialium guineense & Solum & Willd. & Caesalpiniaceae & Guinea \\
\hline Dichrostachys cinerea & Sinc & (L.) Wight et Arn. & Mimosaceae & Sudan \\
\hline Diospyros ferrea & Selax & (Willd.) Bak. & Ebenaceae & Guinea \\
\hline Diospyros mespiliformis & Alom & Hochst. ex A. DC. & Ebenaceae & Guinea \\
\hline Ekebergia capensis & Farxañ & Sparrm. & Meliaceae & Guinea \\
\hline Ekebergia senegalensis & Xak Cooy & A. Juss. & Meliaceae & Guinea \\
\hline Elæis guineensis & Tiir & Jacq. & Palmae & Guinea \\
\hline Entada africana & [Samba] Sayer & Guill. et Perrott. & Mimosaceae & Guinea \\
\hline Erythrina senegalensis & Xunjël [Fall] & DC. & Fabaceae & Guinea \\
\hline
\end{tabular}


Table 1 (continued)

\begin{tabular}{|c|c|c|c|c|}
\hline Species & Wolof name & Botanist & Family & $\begin{array}{l}\text { Vegetation } \\
\text { zone }\end{array}$ \\
\hline Euphorbia balsamifera & Salan & Ait. & Euphorbiaceae & Sahel \\
\hline Fagara xanthoxyloides & Dungidik, dun & Lam. & Rutaceae & \\
\hline GuineaFeretia apodanthera & Sanceer & Del. & Rubiaceae & Sudan \\
\hline Ficus congensis & Xël Baroom & Engl. & Moraceae & Guinea \\
\hline Ficus gnaphalocarpa & Gang & (Miq.) Steud. ex A. Rich. & Moraceae & Guinea \\
\hline Ficus ingens & Sanxay & (Miq.) Miq. & Moraceae & Sahel \\
\hline Ficus iteophylla & Loro, Tat & Miq. & Moraceae & Sudan \\
\hline Ficus platyphylla & Xël Mbap, Xaafor (resprout) & Del. & Moraceae & Guinea \\
\hline Ficus polita & Xameful, Xamesul (South) & Vahl. & Moraceae & Guinea \\
\hline Ficus sp. & Gojji & & Moraceae & Guinea \\
\hline Ficus sp. & Sàkkar & & Moraceae & Guinea \\
\hline Ficus sp. & Sasum & & Moraceae & Guinea \\
\hline Ficus thonningii & Dóobale & Blume & Moraceae & Guinea \\
\hline Gardenia erubescens & Dibuton, Ñasel & Stapf et Hutch. & Rubiaceae & Guinea \\
\hline Grewia bicolor & Kel & Juss. & Tiliaceae & Sahel \\
\hline Grewia flavescens & Xorom Sap bu Jigéen & Juss. & Tiliaceae & Sahel \\
\hline Grewia villosa & Xorom Sap & Willd. & Tiliaceae & Sahel \\
\hline Guiera senegalensis & Nger & J.F. Gmel. & Combretaceae & Sudan \\
\hline Heeria insignis & Waswasor & (Del.) O. Ktze. & Anacardiaceae & Guinea \\
\hline Hexalobus monopetalus & Xaasew (North), Xaasaw & Engl. et Diels & Annonaceae & Guinea \\
\hline Holarrhena floribunda & Selali & H. Huber & Apocynaceae & Guinea \\
\hline Hymenocardia acida & Enkeleñ & Tul. & Euphorbiaceae & Guinea \\
\hline Jatropha chevalieri & Wëttéenu Bët & Beille. & Euphorbiaceae & Sudan \\
\hline Jatropha curcas & Tabanani & Linn. & Euphorbiaceae & Sudan \\
\hline Khaya senegalensis & Xaay & (Desr.) A. Juss. & Meliaceae & Guinea \\
\hline Kigelia africana & Ndambal & Benth. & Bignoniaceae & Guinea \\
\hline Landolphia heudelotii & Tol & A. DC. & Apocynaceae & Guinea \\
\hline Lannea acida & Son & A. Rich. & Anacardiaceae & Guinea \\
\hline Lannea velutina & Songa Bay & Engl. et K. Krause & Anacardiaceae & Guinea \\
\hline Lawsonia inermis & Fuddën & L. & Lythraceae & Sudan \\
\hline Leptadenia pyrotechnica & Ceexaatu [Maam] Yàlla & (Forsk.) Dec. & Asclepiadaceae & Sahel \\
\hline Macrosphyra longistyla & Telteliman & Hook. f. & Rubiaceae & Guinea \\
\hline Maerua angolensis & Tocc [Ñan] & DC. & Capparidaceae & Sudan \\
\hline Maerua crassifolia & Xed & Forsk. & Capparidaceae & Sahel \\
\hline Mangifera indica & Mango & L. & Anacardiaceae & Sudan \\
\hline Maytenus senegalensis & Ndori, Ngandik, Genamdik & (Lam.) Exell. & Celastraceae & Sudan \\
\hline Mitragyna inermis & Xos & (Willd.) O. Ktze. & Rubiaceae & Sudan \\
\hline Moringa oleifera & Sap Sap & Lam. & Moringaceae & Sudan \\
\hline Morus mesozygia & Sànd & Stapf. & Moraceae & Guinea \\
\hline Nauclea latifolia & Nandoob & Sm. & Naucleaceae & Guinea \\
\hline Opuntia linguiformis & Sol & Griff. & Cactaceae & Sudan \\
\hline Opuntia tuna & Gargamboose & (L.) Mill. & Cactaceae & Sudan \\
\hline Parinari marophylla & New & Sabine. & Rosaceae & Sudan \\
\hline Parkia biglobosa & Wul & (Jacq.) Benth. & Mimosaceae & Guinea \\
\hline Phœnix dactylifera & Tàndarma & $\mathrm{L}$. & Palmae & Sahel \\
\hline Phœnix reclinata & Coor, Soor & Jacq. & Palmae & Guinea \\
\hline Piliostigma reticulatum & Ngiigiis & (DC.) Hochst. & Caesalpiniaceae & Sudan \\
\hline Prosopis africana & Yir & (Guill., Perrott., et Rich.) Taub. & Mimosaceae & Guinea \\
\hline Pterocarpus erinaceus & Win & Poir. & Fabaceae & Guinea \\
\hline Pterocarpus lucens & Mbey Mbey, Beey Beey & Lepr. ex Guill. et Perrott. & Fabaceae & Sudan \\
\hline Rhizophora racemosa & Xeex & G.F.W. Mey & Rhizophoraceae & Guinea \\
\hline Ricinus communis & Xeymag, Xexam & L. & Euphorbiaceae & Sudan \\
\hline Salvadora persica & Ngaw & $\mathrm{L}$. & Salvadoraceae & Sahel \\
\hline Sapindus saponaria & Soobaan & $\mathrm{L}$. & Sapindaceae & Guinea \\
\hline Sclerocarya birrea & Bér & (A. Rich.) Hochst. & Anacardiaceae & Sudan \\
\hline Securidaca longipedunculata & Fuuf & Fres. & Polygalaceae & Guinea \\
\hline Securinega virosa & Keng & (Roxb. ex Willd.) Baill. & Euphorbiaceae & Sudan \\
\hline Sterculia setigera & Mbép & Del. & Sterculiaceae & Sudan \\
\hline Stereospermum kunthianum & Feex, Yetu Dëmm, Peex & Cham. & Bignoniaceae & Sudan \\
\hline Strophanthus sarmentosus & Coox, Soox & DC. & Apocynaceae & Sudan \\
\hline Strychnos spinosa & Tëmb & Lam. & Loganiaceae & Guinea \\
\hline
\end{tabular}


Table 1 (continued)

\begin{tabular}{|llll|}
\hline Species & Wolof name & Botanist & Family \\
\hline Swartzia madagascariensis & Dimbeli & Degetation \\
zone
\end{tabular}

covered $60 \%$ of the research area while IGN photos at 1:51700 scale covered $40 \%$. JICA photographed the research area in March 1989, producing photos at a scale of 1:60 000. The JICA photos show superior clarity and resolution. I converted data from the IGN photos at $1: 52500$ and 1:51 700 to data corresponding to 1:60 000 by using a set of IGN 1954 photos at 1:62 687 scale covering $24 \%$ of the research area. Each 1:62 687 photo matched a 1:52 500 photo.

Using an $8 \times$ aplantic lens magnifier, the author counted, for each cell, the trees in a grid of nine 12.5 ha circles spaced at $1.5 \mathrm{~km}$ and centered on the cell center. These counts covered 1209 circles totaling $151 \mathrm{~km}^{2}$. Ground-truthing of the 1989 photos indicated that, in general, only trees of $h \geq 3 \mathrm{~m}$ show under $8 \times$ magnification. The inventory of field trees verified this resolution. A heteroscedastic $t$-test showed no significant difference $(p=0.30)$ between the density of trees $h \geq 3 \mathrm{~m}$ counted in the 135 1-ha quadrats (7.2 \pm 0.9 trees $\mathrm{ha}^{-1}$ ) and the density of trees counted on the 1989 aerial photos in 1209 12.5-ha quadrats (7.8 \pm 0.3 trees $\mathrm{ha}^{-1}$ ).

An original survey of well depths provided data on the depth of the surface water table across the research area. In addition, a published soil and water survey (Stancioff et al. 1986) provided maps of confined aquifer depths, soil types, and geological formations.

Original surveys of ethnic groups, Islamic brotherhood affiliations, infrastructure, and development activities in the 2600 villages in the research area provided fundamental data on the area's population. In addition, government census results (République Française 1938, République du Sénégal 1964, 1982, 1988) provided population by village over time.

\section{RESULTS}

From ca 1945 to 1993 , the average species richness of areas of $4 \mathrm{~km}^{2}$ declined from $64 \pm 2$ to $43 \pm 2$ species, a difference significant at $\mathrm{p}<0.001$ (Gonzalez 1997).
Species richness of Guinean trees and shrubs, the most mesic species, fell by $52 \pm 9 \%$; Sudan species richness fell $29 \pm 4 \%$; the most xeric species, Sahel species, fell by $14 \pm 4 \%$. Aubréville (1950) and Trochain (1940) list the vegetation zones of West African tree and shrub species. The original range maps of the area's 126 tree and shrub species are consistent with the range limits for 67 species drawn by Aubréville (1950) and the limits for 20 species drawn by Trochain (1940).

From 1954 to 1989, densities of trees of $h \geq 3 \mathrm{~m}$ decreased from $10 \pm 0.3$ trees ha ${ }^{-1}$ to $7.8 \pm 0.3$ trees ha ${ }^{-1}$, a difference significant at $\mathrm{p}<0.001$ (Fig. 2). Both the fall in species richness of $33 \pm 5 \%$ over $48 \mathrm{yr}$ and the decrease in tree densities of $23 \pm 5 \%$ over $35 \mathrm{yr}$ translate to a rate of $-0.008 \mathrm{yr}^{-1}$.

Research results clearly show a retraction of the Guinea and the Sudan vegetation zones to the southwest, tracking a concomitant shift of the Sahel from the northeast (Fig. 3). Vegetation zones shifted southwest 25 to $30 \mathrm{~km}$ in the period 1945-1993, an average rate of 500 to $600 \mathrm{~m} \mathrm{yr}^{-1}$. The historical change acted through a higher mortality among mesic species, leaving drought-resistant species to dominate the remaining tree cover.

The decline in mesic species is consistent with pollen analysis of a sediment core from Lac de Guiers, $2 \mathrm{~km}$ northeast of the research area (Lézine 1988). The core yielded the following pollen grain percentages from 2000 yr BP: Sahel spp. 2\%, Sudan spp. 10\%, and Guinean spp. $3 \%$. These changed to the following percentages in the 1980s: Sahel spp. $3 \%$, Sudan spp. 1\%, and Guinean spp. absent. Furthermore, species inventories in 1993 are consistent with pollen analysis of a soil core from the southeast corner of the research area (Lézine \& Edorh 1991). The core yielded current pollen percentages of $3 \%$ for Sahel spp. and $5 \%$ for Sudan spp., consistent with the 33\%:67\% Sahel:Sudan ratio of trees $h \geq 3 \mathrm{~m}$ in 2 southeast cells in 1993 .

The species richness recorded for each cell refers to an area of approximately $4 \mathrm{~km}^{2}$ around each research village. The average 1988 population of the 135 


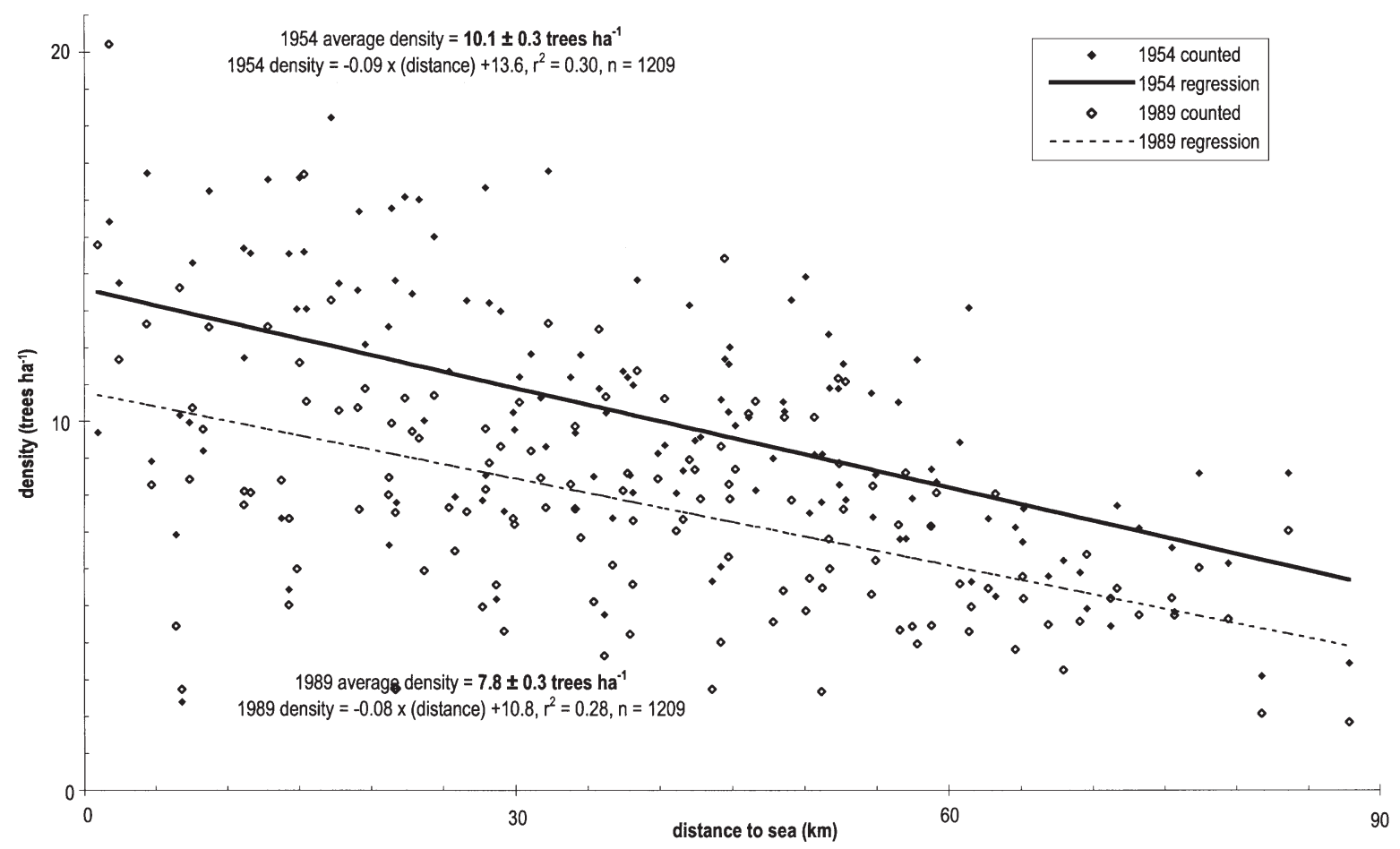

Fig. 2. Decrease in density of trees of height $\geq 3 \mathrm{~m}$ from 1954 to 1989 , from aerial photos. Each point represents average density in 1 of 135 research cells

research villages was 242 , with the populations of 97 out of 135 research villages between 100 and 600. A 1988 rural population density in the research area of 45 people $\mathrm{km}^{-2}$ yields an area of 2.2 ha person ${ }^{-1}$. The product of a village's population and either the research area's average land area per person or the land area per person in each of the 57 cells with a rural population of $>45$ people $\mathrm{km}^{-2}$ produces an estimated average area of research village lands of 440 ha. Species richness ca 1945 and in 1993 showed very weak correlations with calculated area of village lands, $\mathrm{r}=0.16$ and $\mathrm{r}=0.18$ respectively, compared to correlations with longitude, described below, of $r=-0.57$ and $r=-0.70$.

Multivariate analysis using canonical correlations identifies latitude and longitude, proxies for rainfall and temperature, as the most significant factors, out of 215 ecological and socioeconomic variables, explaining the variance in the distribution, densities, and changes in trees and shrubs in the research area (Gonzalez 1997). For the 15 most significant factors identified by correlation coefficients, $t$-tests, ANOVA, gradient analyses, and principal components analyses, a final
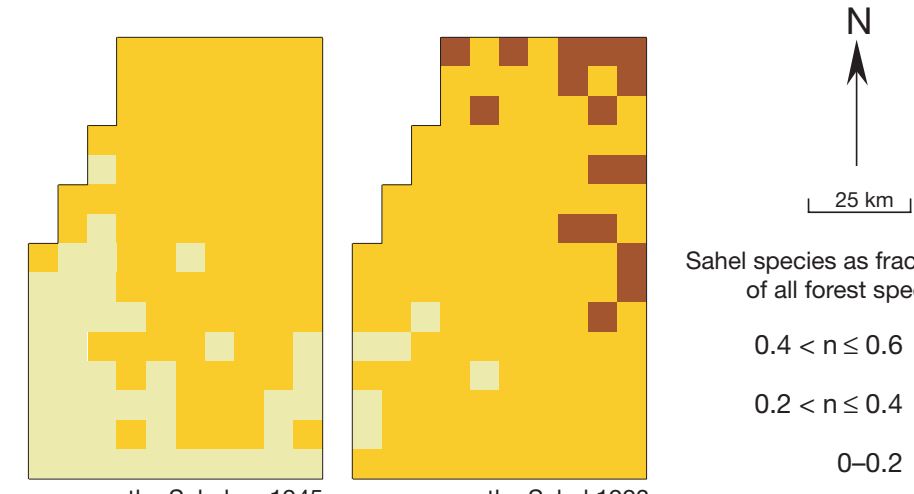

Sahel species as fraction of all forest species

$0.4<\mathrm{n} \leq 0.6$

$0.2<\mathrm{n} \leq 0.4$

$0-0.2$
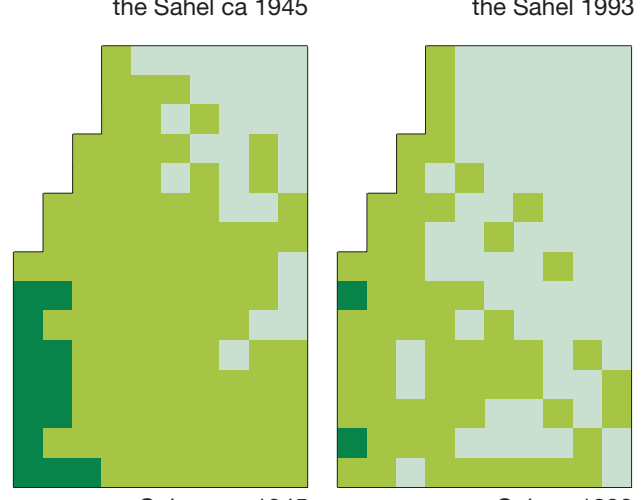

Guinean species as fraction of all forest species

$0.4<\mathrm{n} \leq 0.6$

$0.2<\mathrm{n} \leq 0.4$

$0-0.2$

Guinea 1993

Fig. 3. Shift of the Sahel and Guinean vegetation zones in Northwest Senegal $\left(15^{\circ} 00^{\prime}\right.$ to $16^{\circ} 01^{\prime} \mathrm{N}, 16^{\circ} 00^{\prime}$ to $\left.16^{\circ} 42^{\prime} \mathrm{W}\right)$ from ca 1945 to 1993 
canonical correlations analysis yielded rotated loadings of -0.91 for longitude on factor 1 and 0.97 for latitude on factor 2 .

Standing biomass in the research area in 1993 averaged $15 \mathrm{t} \mathrm{ha}^{-1}$, with wood comprising $12 \mathrm{t} \mathrm{ha}^{-1}$. The standing biomass of trees across the research area decreased by $2.1 \mathrm{t} \mathrm{ha}^{-1}$ in the period 1956-1993, matching a cumulative firewood deficit in the same period of $2.1 \mathrm{t} \mathrm{ha}^{-1}$. The 1956-1988 rate of reduction in standing biomass of $140 \mathrm{~kg}$ person ${ }^{-1} \mathrm{yr}^{-1}$ released carbon into the atmosphere at a rate of $60 \mathrm{kgC} \mathrm{person}^{-1}$ $\mathrm{yr}^{-1}$ (Gonzalez 1997), somewhat less than the $100 \mathrm{kgC}$ person $^{-1} \mathrm{yr}^{-1}$ released (World Bank 1996) from the burning of fossil fuels.

In 1993, total wood production was $190 \mathrm{~kg} \mathrm{ha}^{-1} \mathrm{yr}^{-1}$ out of a total net primary productivity (NPP) of $3.1 \mathrm{tha}^{-1} \mathrm{yr}^{-1}$. The rate of energy fixation in NPP averaged $1.7 \mathrm{~kW} \mathrm{ha}{ }^{-1}$, of which humans directly used $210 \mathrm{~W} \mathrm{ha}^{-1}$, based on firewood use of $450 \mathrm{~kg}$ person $^{-1}$ $\mathrm{yr}^{-1}$ by Wolof and $380 \mathrm{~kg}$ person ${ }^{-1} \mathrm{yr}^{-1}$ by Fulbe (Berger 1989) and urban charcoal use of $95 \mathrm{~kg}$ person ${ }^{-1} \mathrm{yr}^{-1}$ (CTFT 1989).

Analyses of forestry and population data show that rural firewood use exceeds firewood production from shrubs over $89 \%$ of the research area, affecting $95 \%$ of the rural population (Gonzalez 1997). The rural population density of 45 people $\mathrm{km}^{-2}$ exceeded the 1993 carrying capacity of firewood from shrubs of 13 people $\mathrm{km}^{-2}$ (range 1 to 21 people $\mathrm{km}^{-2}$ ). Population data indicate that rural population density has exceeded carrying capacity since 1956. In addition, the sum of rural and urban charcoal use and urban firewood use exceeded the wood production of tree trunks. Conversely, wood production from trunks exceeded rural charcoal use alone, and the production of poles measuring $3 \mathrm{~m} \times 0.15 \mathrm{~m}$ exceeded rural pole use.

\section{DISCUSSION}

The results of this research document a long-term change in forest vegetation in the Sahel. The 500 to $600 \mathrm{~m} \mathrm{yr}^{-1}$ shift of forest species from ca 1945 to 1993 and the decline in tree densities from 1954 to 1989 constitute unique evidence for land degradation and desertification in the Sahel. Moreover, the 500 to $600 \mathrm{~m}$ $\mathrm{yr}^{-1}$ average rate of change foreshadows the projected rate of vegetation shifts in North America driven by climate change (Davis \& Zabinski 1992, IPCC 1996).

This shift of xeric Sahel species into mesic Guinean areas in the Sahel is similar to a permanent $2000 \mathrm{~m}$ shift of xeric piñon-juniper woodland into mesic ponderosa pine forest in New Mexico, USA, caused by a 1954-1958 drought in which precipitation there fell to its lowest recorded levels (Allen \& Breshears 1998).
The multivariate analyses of the data from northwest Senegal show that rainfall and temperature most explain the variance in the distribution, densities, and changes in forest species in the research area. Indeed, the shift in forest species follows a southward shift of isohyets, or lines of equal rainfall, in the Sahel during the same period. Analyses by the Centre Regional AGRHYMET, the institution that maintains the rainfall data archive for the Sahel countries, show that the $300 \mathrm{~mm} \mathrm{yr}^{-1}$ isohyet shifted south $100 \mathrm{~km}$ between the periods 1950-1967 and 1968-1997 (CILSS 2000).

Since 1968, the Sahel has experienced the most substantial and sustained decline in rainfall recorded in the world within the period of instrumental measurements (Nicholson 2000). Linear regression of 1901-1990 rainfall data from 24 stations in the West African Sahel yields a negative slope amounting to a fall of 1.9 standard deviations in the period 1950-1985 (Nicholson \& Palao 1993). Since 1971, the average of all stations fell below the $89 \mathrm{yr}$ average and showed a persistent downward trend since 1951. Within the research area itself, linear regressions of 1855-1993 rainfall data at St. Louis (Ndar) (Fig. 1) and of 1919-1993 rainfall data at Louga also yield negative slopes.

The multivariate analyses seem to indicate that climatic factors override local anthropogenic factors in explaining the overall changes in vegetation. Examination of dead trees along the coast supports a predominance of climatic over local anthropogenic factors. Dead trees and stumps cluster along the coast such that $55 \%$ of the calculated dead woody biomass in all quadrats occurs within $12 \mathrm{~km}$ of the sea, compared to an average distance to the sea of $40 \mathrm{~km}$ for all 135 quadrats. Many dead trees along the coast still stand, but show no ax marks or any sign that humans directly caused their death. The sparsely populated coast offers a view of the state of the countryside before cultivation. For example, natural stands of Euphorbia balsamifera still occur there. In contrast, elsewhere in the Senegal Sahel, farmers have cut all natural stands of this species and replanted it along field boundaries. In the collective memory of local people, the vast areas along the coast have not been cultivated. The absence of intensive agriculture renders less likely a local anthropogenic cause for the death of the coastal trees. Nevertheless, anthropogenic factors on a regional scale, described below, may still have caused the decline in Sahel rainfall, and, therefore, in the changes in forest species in the Senegal Sahel.

Efforts to determine the relative importance of anthropogenic and climatic factors in explaining the long-term rainfall decline in the Sahel have produced evidence pointing both to changes in land cover (Charney 1975, Schlesinger et al. 1990, Xue \& Shukla 1993, 
Wallace et al. 1994, Dirmeyer \& Shukla 1996, Xue 1997, Claussen et al. 1999, Zeng et al. 1999, Wang \& Eltahir 2000) and to changes in sea-surface temperatures (SST) (Lamb 1978, Folland et al. 1986, StreetPerrott \& Perrott 1990, Rowell et al. 1995, Myneni et al. 1996, Nicholson \& Kim 1997, Hulme et al. 1999).

A positive feedback mechanism between albedo, and therefore vegetation cover, and precipitation may help explain the Sahel drought (Charney 1975). Some research supports an albedo-precipitation feedback mechanism (Otterman 1974, Cunnington \& Rowntree 1986, Xue et al. 1990, Diedhiou \& Mahfouf 1996, Zheng \& Eltahir 1997, Zeng et al. 1999), although other research disputes the importance of albedo (Jackson \& Idso 1974, Ripley 1976, Wendler \& Eaton 1983, Gornitz \& NASA 1985, Nicholson et al. 1998).

Recent modeling and observations (Diedhiou \& Mahfouf 1996, Xue 1997, Zeng et al. 1999, Wang \& Eltahir 2000) demonstrate that a combination of factors, including vegetation cover, soil moisture, and $\mathrm{SST}$, best explains the reduction of rainfall in the Sahel and that vegetation cover predominates among these factors. Diedhiou \& Mahfouf (1996) modeled changes in albedo, soil moisture, land surface roughness, and $\mathrm{SST}$ and calculated a rainfall deficit over the Sahel similar to observed rainfall. Xue (1997) used coupled biosphere and general circulation models to show that observed rainfall and runoff declines in the Sahel result from reductions in moisture storage and availability caused by degradation of vegetation. Zeng et al. (1999) compared actual rainfall data from the period 1950-1998 with the output of a coupled atmosphereland-vegetation model incorporating SST, soil moisture, and vegetative cover. Their results indicate that actual rainfall anomalies are only weakly correlated to SST by itself. Only when the model includes variations in vegetative cover and soil moisture does it come close to matching actual rainfall data. Another coupled surface-atmosphere model (Wang \& Eltahir 2000) indicates that, whether anthropogenic factors or changes in SST initiated the Sahel drought of 1968-1973, permanent loss of Sahel savanna vegetation would permit the drought conditions to persist.

In effect, because evapotranspiration constitutes the only local input to the hydrologic cycle besides surface water, a reduction in vegetative cover leads to reduced precipitation, initiating a positive feedback cycle. Therefore, degradation of vegetation cover in moister areas south of the Sahel may have decreased continental evapotranspiration and reduced precipitation in the Sahel. The results of Xue (1997), Zeng et al. (1999), and Wang \& Eltahir (2000) support a mechanism proposed by Aubréville (1949), namely, that deforestation of tropical rainforests in the Congo vegetation zone from the Republic of Guinea to Côte d'Ivoire may have reduced the evapotranspiration inputs essential to the maintenance of the southwest monsoon. Reduced rainfall over an extended period would reduce the vegetation cover in the Guinean zone to the north. This in turn would decrease rainfall and vegetation farther north in the Sudan, eventually reducing rainfall and vegetation in the Sahel. Human activities in the distant rainforests may initiate a concatenation of climatic changes that ultimately touch the Sahel.

The research results on human carrying capacity in Northwest Senegal show that not only do the quantitative uses of firewood and charcoal exceed the area's wood production, but that the fall in species richness has also reduced people's options qualitatively. For example, rural women depend on 2 particular shrub species for firewood because of the size of the branches, high wood density, and ease of collection. Beyond that, few fallback species remain. The fraction of women that reported shrub species as most prevalent in firewood use fell from $87 \%$ ca 1945 to $50 \%$ in 1993. With respect to traditional medicine, 25 useful species have diminished significantly. Furthermore, 8 species that provided fruit, leaves, and gum in past droughts have disappeared from as much as $53 \%$ of their range. If a grave famine hit the area in its current condition, people would not be able to find the emergency foods that saved others in past episodes.

To restore the human carrying capacity of this arid land, ecological and socioeconomic factors favor the natural regeneration of local species over the massive plantation of exotic species. Because of a lack of water, massive plantations of Eucalyptus camaldulensis and other exotics by foreign aid projects in the region show a survival rate of only $18 \%$, leading to costs of up to $\$ 50$ per surviving tree (Gonzalez 1997). The only successful exotic plantation efforts include $\$ 22$ million of maritime dune plantations of Casuarina equisetfolia along the Atlantic coast, which the government keeps off-limits to rural villagers, and individual shade plantings of Azadirachta indica and Prosopis juliflora in villages and along roads. Nevertheless, plantations account for only $0.4 \%$ of the standing biomass and $3 \%$ of the wood production in the research area.

Farmers and herders in Africa have traditionally adapted to arid and semi-arid conditions by promoting the natural regeneration of trees and shrubs. Natural regeneration is a practice in which farmers and herders seek to reconstitute the vegetative cover either by setting aside parcels of land or by selecting small trees in their fields, protecting them, pruning them to promote rapid growth of the apical meristem, and raising them to maturity. The practice requires no special inputs and encourages the propagation of well-known, multipleuse trees. The Sereer in Senegal (Lericollais 1973) and the Mossi in Burkina Faso (Kessler 1992) have doubled 
tree densities in certain semi-arid areas with Acacia albida and Butyrospermum parkii, respectively.

In the research area, small trees $(h<40 \mathrm{~cm})$ occur at a density of $160 \pm 18$ trees ha ${ }^{-1}$, over $20 \times$ the density of adult trees $(h \geq 3 \mathrm{~m})$. Because drought-tolerant Sahel species account for $37 \%$ of small trees, natural regeneration under current climatic conditions could potentially reconstitute the vegetative cover. In the semistructured interviews, $77 \%$ of local people favored natural regeneration of local species over plantation of exotics. In a survey of 27 forestry project directors and technical advisors across Senegal, 67\% also favored natural regeneration (Gonzalez 1997).

According to local people, the browsing of livestock and the seasonal clearing of agricultural fields most threaten small trees. Traditional live fencing using Euphorbia balsamifera and thorny branches together with the social fencing of village agreements and surveillance would allow drought-tolerant trees to flourish, as demonstrated by stands of Acacia albida of $h \geq$ $3 \mathrm{~m}$ at up to 20 trees $\mathrm{ha}^{-1}$ in densely populated parts of the research area.

\section{CONCLUSION}

Original field data show that forest species richness in northwest Senegal fell 33\% from ca 1945 to 1993. Densities of trees of $h \geq 3 \mathrm{~m}$ declined $23 \%$ from 1954 to 1989. These changes shifted the Sahel, Sudan, and Guinean vegetation zones towards areas of higher rainfall at an average rate of 500 to $600 \mathrm{~m} \mathrm{yr}^{-1}$. The changes also decreased human carrying capacity below actual population densities. The possibility of future droughts in the Sahel raises the specter of another grave episode sometime in the 21st century. Yet, this research shows that the impoverished flora may have lost its capacity to provide aid to a substantial population ravaged in the future by famine. This renders imperative a sustainable system of resource management. Ultimately, only natural regeneration can cover an extensive surface area, a condition necessary not only to map a comprehensive system of natural resource management, but also to engage positive climatic effects. In the face of desertification and climate change, sustainable natural resource management in the Sahel depends on natural regeneration.

Acknowledgements. The author wishes to thank John P. Holdren and Richard S. Dodd, Dawda Jóob, Séex Ley, and Richard B. Norgaard for making the research possible. The author gratefully acknowledges funding from a Fulbright Award, from the UC Berkeley Vice Chancellor for Research, and from the Conservation and Research Foundation. The Heinz Family Foundation and the Winslow Foundation provided funding through grants to Dr Holdren.

\section{LITERATURE CITED}

Allen CD, Breshears DD (1998) Drought-induced shift of a forest-woodland ecotone: rapid landscape response to climate variation. Proc Natl Acad Sci USA 95:14839-14842

Aubréville A (1938) La forêt coloniale - Les forêts de l'Afrique Occidentale Française. Société d'Éditions Géographiques, Maritimes, et Coloniales, Paris

Aubréville A (1949) Climats, forêts, et désertification de l'Afrique tropical. Société d'Éditions Géographiques, Maritimes, et Coloniales, Paris

Aubréville A (1950) Flore forestière Sudano-Guinéenne. Société d'Éditions Géographiques, Maritimes, et Coloniales, Paris

Berger D (1989) Étude qualitative et quantitative de la consommation en combustibles dans 50 villages. Projet de Boisements Villageois Intégrés à Louga, Dakar

Carruthers I, Chambers R (1981) Rapid appraisal for rural development. Agric Admin 8:407-422

Catinot R (1967) Sylviculture tropicale dans les zones sèches de l'Afrique. Bois For Trop 111:19-32

Cazet M (1989) Les plantations linéaires denses sur les sols sableux dégradés de la zone centre-nord du Sénégal. Bois For Trop 222:27-37

Centers for Disease Control (CDC) (1973) Nutritional surveillance in drought affected areas of West Africa (Mali, Mauritania, Niger, Upper Volta). CDC, US Public Health Service, Atlanta, GA

Centre de Suivi Écologique (CSE) (1993) Suivi de la production végétale 1993: situation des parcours naturels. CSE, Dakar

Centre Technique Forestier Tropical (CTFT) (1989) Mémento du forestier 3e édition. Ministère de la Coopération et du Développement, Paris

Chambers R, Pacey A, Thrupp LA (eds) (1989) Farmer first. Intermediate Technology Publications, London

Charney JG (1975) Dynamics of deserts and drought in the Sahel. Q J R Meteorol Soc 101:193-202

Claussen M, Kubatzki C, Brovkin V, Ganopolski A, Hoelzmann P, Pachur HJ (1999) Simulation of an abrupt change in Saharan vegetation in the mid-Holocene. Geophys Res Lett 26:2037-2040

Comité Permanent Inter-États de Lutte contre la Sécheresse dans le Sahel (CILSS) (2000) Programme d'action sousrégional de lutte contre la désertification en Afrique de l'Ouest et au Tchad. CILSS, Ouagadougou

Coughenour MB, Ellis JE, Popp RG (1990) Morphometric relationships and developmental patterns of Acacia tortilis and Acacia reficiens in Southern Turkana, Kenya. B Torrey Bot Club 117:8-17

Cunnington WM, Rowntree PR (1986) Simulations of the Saharan atmosphere-dependence on moisture and albedo. Q J R Meteorol Soc 112:971-999

Davis MB, Zabinski C (1992) Changes in geographical range resulting from greenhouse warming effects on biodiversity in forests. In: Peters RL, Lovejoy TE (eds) Global warming and biological diversity. Yale University Press, New Haven, CT

Diedhiou A, Mahfouf JF (1996) Comparative influence of land and sea surfaces on the Sahelian drought: a numerical study. Ann Geophys 14:115-130

Dirmeyer PA, Shukla J (1996) The effect on regional and global climate of expansion of the world's deserts. Q J R Meteorol Soc 122:451-482

Folland CK, Palmer TN, Parker DE (1986) Sahel rainfall and worldwide sea temperatures, 1901-1985. Nature 320: 602-607 
Food and Agriculture Organization (FAO) (1999) State of the world's forests 1999. FAO, Rome

Frankenberg P, Anhuf D (1989) Zeitlicher Vegetations- und Klimawandel im westlichen Senegal. Franz Steiner Verlag Wiesbaden $\mathrm{GmbH}$, Stuttgart

Giffard PL (1967) Le palmier rônier Borassus æthiopium Mart. Bois For Trop 116:3-13

Gonzalez P (1997) Dynamics of biodiversity and human carrying capacity in the Senegal Sahel. PhD dissertation, University of California, Berkeley

Gornitz V, National Aeronautics and Space Administration (NASA) (1985) A survey of anthropogenic vegetation changes in West Africa during the last century - climatic implications. Climatic Change 7:285-325

Gorse JP (1985) Desertification in the Sahelian and Sudanian zones of West Africa. Unasylva 37:2-18

Hulme M (1992) Rainfall changes in Africa (1931-1960 to 1961-1990). Int J Climatol 12:658-690

Hulme M, Barrow EM, Arnell N, Harrison PA, Downing TE, Johns, TC (1999) Relative impacts of human-induced climate change and natural climate variability. Nature 397: 688-691

Intergovernmental Panel on Climate Change (IPCC) (1996) Climate change 1995-impacts, adaptations, and mitigation of climate change: scientific-technical analyses. Cambridge University Press, Cambridge

Jackson RD, Idso SB (1974) Surface albedo and desertification. Science 189:1012-1013

Kessler JJ (1992) The influence of karité (Vitellaria paradoxa) and néré (Parkia biglobosa) trees on sorghum production in Burkina Faso. Agroforest Syst 17:97-118

Kessler JJ (1994) Usefulness of the human carrying capacity concept in assessing ecological sustainability of land-use in semi-arid regions. Agric Ecosyst Environ 48:273-284

Lamb PJ (1978) Large-scale tropical Atlantic surface circulation patterns associated with subsaharan weather anomalies. Tellus 30:240-251

Le Houérou HN (1989) The grazing land ecosystems of the African Sahel. Springer-Verlag, Berlin

Lericollais A (1973) Sob-étude géographique d'un terroir Serer (Sénégal). Office de la Recherche Scientifique et Technique Outre-Mer, Paris

Lericollais A (1988) Evolution du parc arboré en pays Sereer. Office de la Recherche Scientifique et Technique OutreMer, Dakar

Lézine AM (1988) New pollen data from the Sahel, Senegal. Rev Palaeobot Palyno 55:141-154

Lézine AM, Edorh TM (1991) Modern pollen deposition in West African Sudanian environments. Rev Palaeobot Palyno 67:41-58

Maignien R (1965) Carte pédologique du Sénégal au 1/1 000 000. Office de la Recherche Scientifique et Technique Outre-Mer, Dakar

Milne A (1959) The centric systematic area-sample treated as a random sample. Biometrics 15:270-297

Myneni RB, Los SO, Tucker CJ (1996) Satellite-based identification of linked vegetation index and sea surface temperature anomaly areas from 1982-1990 for Africa, Australia, and South America. Geophys Res Lett 23:729-732

Nicholson SE (2000) Land surface processes and Sahel climate. Rev Geophys 38:117-139

Nicholson SE, Kim J (1997) The relationship of the El Niño Southern Oscillation to African rainfall. Int J Climatol 17: 117-135

Nicholson SE, Palao IM (1993) A re-evaluation of rainfall variability in the Sahel. Part I. Characteristics of rainfall fluctuations. Int J Climatol 13:371-389
Nicholson SE, Tucker CJ, Ba MB (1998) Desertification, drought, and surface vegetation: an example from the West African Sahel. Bull Am Met Soc 79:815-829

Olsson K (1984) Long-term changes in the woody vegetation in N. Kordofan, The Sudan. Lunds Universitets Naturgeografiska Institution, Lund

Otterman J (1974) Baring high-albedo soils by overgrazing: a hypothesized desertification mechanism. Science 186: 531-533

Poupon H (1980) Structure et dynamique de la strate ligneuse d'une steppe Sahélienne au nord du Sénégal. Office de la Recherche Scientifique et Technique Outre-Mer, Paris

République du Sénégal (1964) Résultats de l'enquête démographique 1960/61, données régionales. Ministère du Plan et du Développement, Service de la Statistique, Dakar

République du Sénégal (1982) Recensement générale de la population d'Avril 1976, résultats définitifs, données corrigées. Ministère de l'Economie et des Finances, Direction de la Statistique, Dakar

République du Sénégal (1988) Répertoire des villages. Ministère de l'Economie, des Finances, et du Plan, Direction de la Prévision et de la Statistique, Dakar

République du Sénégal (1991) Cartes au 1:50 000 ND-28-XX Louga. Japanese International Cooperation Agency and Ministère Sénégalais de l'Équipement des Transports et du Logement, Dakar

République du Sénégal (1992) Population du Sénégal: structure par sex et par age en 1988 et projections de 1989 à 2015. Ministère de l'Economie, des Finances, et du Plan, Direction de la Prévision et de la Statistique, Dakar

République Française (1925) Reboisement du Sénégal et de la Mauritanie. Gouvernement Générale de l'Afrique Occidentale Française, Service de l'Agriculture et des Forêts, St. Louis, Senegal

République Française (1938) Résumé statistique du recensement générale de la population effectué le 8 mars 1936. Imprimerie Nationale, Paris

République Française (1950) Annuaire statistique de l'Afrique Occidentale Française, édition 1949. Imprimerie Nationale, Paris

Ripley EA (1976) Drought in the Sahara: insufficient biogeophysical feedback? Science 191:100

Rowell DP, Folland CK, Maskell K, Ward MN (1995) Variability of summer rainfall over tropical North Africa (1906-92) - observations and modeling. Q J R Meteorol Soc 121:669-704

Schlesinger WH, Reynolds JF, Cunningham GI, Huennecke LF, Jarrell WM, Virginia RA, Whitford WG (1990) Biological feedbacks in global desertification. Science 247: 1043-1048

Shantz HL, Turner BL (1958) Photographic documentation of vegetation changes in Africa over a third of a century. University of Arizona College of Agriculture, Tuscon

Stancioff A, Staljanssens M, Tappan G (1986) Mapping and remote sensing of the resources of the Republic of Senegal. South Dakota State University Remote Sensing Institute, Brookings

Street-Perrott FA, Perrott, RA (1990) Abrupt climate fluctuations in the tropics: the influence of Atlantic Ocean circulation. Nature 343:607-612

Trochain J (1940) Contribution à l'étude de la végétation du Sénégal. Institut Français d'Afrique Noire, Paris

Tucker CJ (1979) Red and photographic infrared linear combinations for monitoring vegetation. Remote Sens Environ 8:127-150

United Nations (UN) (1999) World population prospects: the 1998 revision. UN Department for Economic and Social 
Information and Policy Analysis, New York

United Nations Conference on Desertification (UNCOD) (1977) Desertification: its causes and consequences. Pergamon Press, Oxford

United Nations Convention to Combat Desertification (UNCCD) (1994) United Nations, New York

United Nations Development Program (UNDP) (1997) Aridity zones and dryland populations: an assessment of population levels in the world's drylands. UNDP Office to Combat Desertification and Drought, New York

United Nations Environment Program (UNEP) (1997) World atlas of desertification, 2nd edn. Edward Arnold, London

Vansina J (1961) De la tradition orale: essai de méthode historique. Musée Royal de l'Afrique Centrale, Tervuren

Wallace JS, Gash JHC, Sivakumar MVK (1994) Measurements of albedo variation over natural vegetation in the Sahel. Int J Climatol 14:625-636

Wang G, Eltahir EAB (2000) Ecosystem dynamics and the Sahel drought. Geophys Res Lett 27:795-798

Wendler G, Eaton F (1983) On the desertification of the Sahel zone. Clim Change 5:365-380

White F (1983) The vegetation of Africa. UNESCO, Paris

Submitted: December 10, 1999; Accepted: January 30, 2001
World Bank (1996) World development report 1996. Oxford University Press, New York

World Bank (1998) The World Bank and the environment: environment matters at the World Bank. International Bank for Reconstruction and Development, Washington, DC

Xue Y (1997) Biosphere feedback on regional climate in tropical North Africa. Q J R Meteorol Soc 123:1483-1515

Xue Y, Shukla J (1993) The influence of land-surface properties on Sahel climate. Part I: desertification. J Clim 6: 2232-2245

Xue Y, Liou KN, Kasahara A (1990) Investigation of biogeophysical feedback on the African climate using a twodimensional model. J Clim 3:337-352

Zanté P (1984) Étude de reconnaissance des sols aux aptitudes forestiers-Projet Louga. Office de la Recherche Scientifique et Technique Outre-Mer, Dakar

Zeng N, Neelin JD, Lau KM, Tucker CJ (1999) Enhancement of interdecadal climate variability in the Sahel by vegetation interaction. Science 286:1537-1540

Zheng X, Eltahir EAB (1997) The response to deforestation and desertification in a model of West African monsoons. Geophys Res Lett 24:155-158

Proofs received from author(s): April 12, 2001 